Pregledni rad

Primljen: 5. 11. 2016.

UDK: 343.985

Revidirana verzija: 1. 2. 2017.

343.123 .12

Prihvaćen: 17. 5. 2017.

doi: $10.5937 /$ nabepo22-12310

\title{
EFFECTIVE INVESTIGATIVE INTERVIEWING: TURNING INTERROGATIONS INTO CONVERSATIONS
}

\author{
Stephen Grossman ${ }^{1}$
}

Sykes \& Burrows, London, United Kingdom

\begin{abstract}
An interrogation is essentially combative and high pressure, and therefore most often a negatively charged monologue of an interrogator trying to work a confession out of a subject. In the following, there should be removed from any ethical, effective investigative interviewing practice: interrogation, combative, pressure, monologue and confession.

Effective, ethical investigative interviews should be conversational, non-combative and should not seek confessions as a primary objective. Pressuring subjects (including suspects, witnesses or victims) forces people to lie, go silent or to become uncooperative. Pressure and accusations trigger defensive responses. They also cause panic and fear which impacts a person's cognitive ability to remember and even to communicate. How often people in shock are left stuttering or unable to form coherent sentences or to remember a question asked seconds earlier?

Combine the intimidation of being questioned by police, the fear of going to jail and the humiliation of being judged badly by people in authority or by one's family and friends, as well as fear of reprisals for informing on other criminals, and one easily ends up with "no comment" interviews or flat out lies. Forcing subjects to admit a
\end{abstract}

1 stephen.grossman@sykesandburrows.com 
version of events in order to overcome "no comment" responses or flat out lies leads to poor conviction rates and wrongful convictions. The alternative, which has proven highly effective when practiced within a well-defined, controlled process, is a managed conversation that relaxes a subject and provides an environment and communication framework that inspires an exchange.

Keywords: investigation, interview, profiling, interrogation, negotiation

\section{Introduction}

An interrogation is essentially combative and high pressure, and therefore most often a negatively charged monologue of an interrogator trying to work a confession out of a subject. Of the words and concepts in the previous sentence, the following should be removed from any ethical, effective investigative interviewing practice: interrogation, combative, pressure, monologue and confession.

Effective, ethical investigative interviews should be conversational, ${ }^{2}$ non-combative and should not seek confessions as a primary objective. Pressuring subjects (including suspects, witnesses or victims) forces people to lie, go silent or to become uncooperative. Pressure and accusations trigger defensive responses. They also cause panic and fear which impacts a person's cognitive ability to remember and even to communicate. How often people in shock are left stuttering or unable to form coherent sentences or to remember a question asked seconds earlier?

Combine the intimidation of being questioned by police, the fear of going to jail and the humiliation of being judged badly by people in authority or by one's family and friends, as well as fear of reprisals for informing on other criminals, and one easily ends up with "no comment" interviews or flat out lies. Forcing subjects to admit a version of events in order to overcome "no comment" responses ${ }^{3}$ or flat out lies leads to poor conviction rates and wrongful convictions.

The alternative, which has proven highly effective when practiced within a well-defined, controlled process, is a managed conversation that relaxes a subject and provides an environment and communication framework that inspires an exchange.

2 Shepherd E. Griffiths, A. Investigative Interviewing: The Conversation (2 $2^{\text {nd }}$ Edition, 2013), Oxford University Press

3 Walsh D. Bull, R. How Do Interviewers Attempt to Overcome Suspects' Denials, Psychiatry, Psychology \& Law, 5 
The best and most comprehensive approach to this form of conversation management is the PEACE model developed in the United Kingdom. PEACE stands for Planning \& Preparation, Engage \& Explain, Account, Clarification \& Challenge, Closure, and Evaluation. The interview method, first developed in the UK in the early 1990s as a means of repairing the damage created by decades of miscarriages of justice, is now the standard bearer in effective, ethical investigative interviewing.

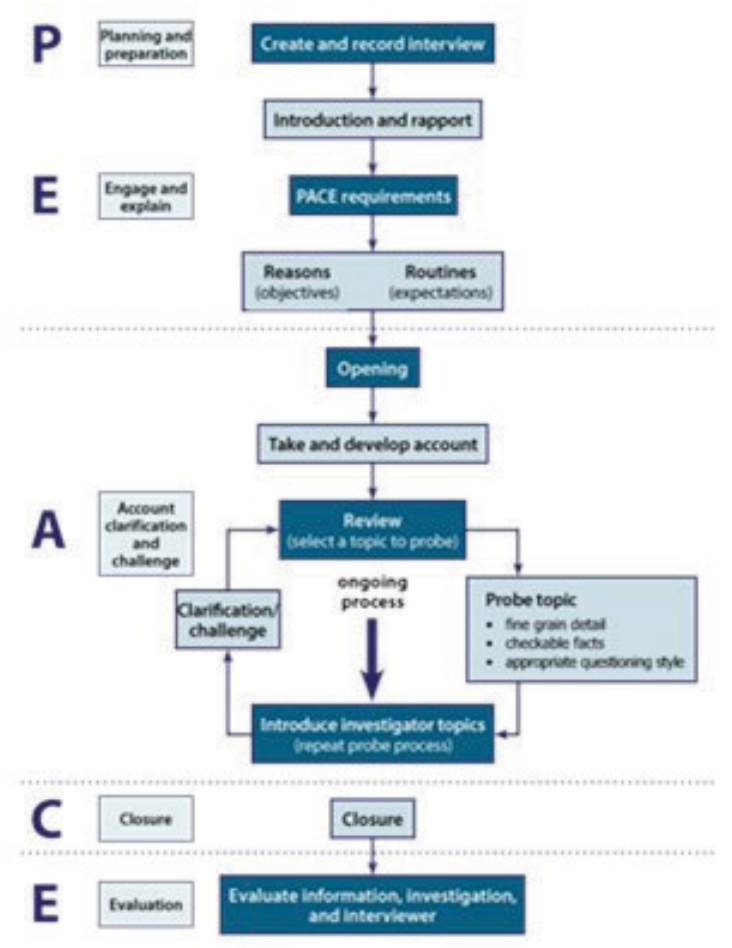

(Source: http://www.app.college.police.uk/app-content/investigations /investigative-interviewing, October 23, 2013)

By establishing rapport, explaining the interview process carefully to a suspect or witness, asking open-ended questions, allowing subjects the opportunity to provide alternate explanations of events, and applying SUE (Strategic Use of Evidence), interviewers can improve results of various types of interviews. Witness memory, for instance, can recover and be more accurate when conducting free recall interviews based on PEACE that stimulate memory by relaxation and free association of the senses to a narrative timeline, similar to a Cognitive Interview. Suspect interviews can yield actionable intelligence or new lines of enquiry by allowing subjects to establish their own version of 
events that can be questioned further or challenged by strategic use of evidence; and provided the challenges are not presented in a manner that breaks down rapport, the suspect's response to the challenge often reveals new information, confirms suspicions, disproves a working theory and/or provides additionally valuable insight into the suspect's motivations or emotions relevant to the event or to the people involved.

This approach requires police interviewers to prepare for the interview, to conduct active listening, to apply behavioural communication methods, to have strong emotional intelligence in order to establish rapport and to be able to "read" the subject accurately, to detect deception, and to exercise control whether when managing a "no comment" interview or when reaching a breakthrough when a suspect inadvertently indicts himself.

\section{Preparing for the interview}

Once a proper timeline or workable preliminary timeline of events is established and all currently available physical evidence is gathered, a working theory of the events can be established. This working theory should take into account plausible explanations both for prosecution and for defence. This will allow room for the investigation team and the subject to establish or to present new theories, new leads and adjustments to the timetable.

A key piece of evidence often overlooked or, worse, never considered is a Self-Administered Statement ("SAS") produced by the subject himself/herself. The SAS comes with a simple, carefully worded set of instructions that do not frame the subject's answers in terms of time frames, sequence of events, presumptions of guilt, etc. The instructions simply state that the subject should tell what happened (with no reference to a start or stop date of the event in question) in their own words, using a pen and crossing out any mistakes or corrections without concern, and to use as much blank paper as needed.

The SAS should be analysed prior to conducting any formal interview with the subject. The SAS is a map that can lead investigators to new understanding of events, provide insight into the subject, ${ }^{4}$ indicate new viable lines of enquiry and uncover new evidence.

All the evidence available at the time, including the SAS, should be sorted in terms of a place within the constantly developing timeline and in a sequence that best supports the planned strategy for the interview.

4 Picornell, I. Analysing Deception in Written Witness Statements, Linguistic Evidence in Security, Law \& Intelligence, Vol. 1 (No. 1) 2013

[144] NBP • Žurnal za kriminalistiku i pravo 
Interview strategies are shaped with a consideration for the profile of the subject being interviewed and with thought as to whether the subject is a suspect, witness or victim. A criminal with form who knows police procedures and/or one who is part of an organised criminal group is not likely to cooperate willingly in the interview and would be expected to provide a consistent "no comment" interview. This type of subject requires a different approach, a different sequence and presentation of the case than a first time offender who shows no sign of psychopathy or sociopathy and who is capable to feel remorse or regret for his/her actions.

The key is to structure the lines of questions and the available evidence in a way that supports a narrative best told or confirmed by the subject. Evidence to be introduced in the interview should be selected carefully - building from more circumstantial and general or vague pieces of evidence to more indisputable, i.e. from witness statements or blurry CCTV footage to copies of receipts and high resolution close ups from CCTV, etc. This allows a subject to be honest and tell his/her story from the start but exposes their lies unquestionably should the subject choose to lie to the interviewer. The effect of getting caught in a lie is much more powerful, far more ethical and has greater forensic value in court than accusing a subject and getting him/her to sign a statement of fact written by a police officer.

\section{Rapport building}

As the aim of the investigative interview is conversation and not interrogation, building a genuine rapport with the subject is crucial. That mysterious form of connection and strange kind of trust that is rapport. The je ne sais quoi of effective interviewing is an essential ingredient that cannot be ignored or replaced with a false substitute in the recipe.

Rapport requires empathy. If an interviewer cannot put himself/herself in the shoes of the subject, it will be impossible to establish the kind of understanding and non-judgemental environment necessary for an effective conversation to take place. ${ }^{5}$

The interviewer must not only have empathy but must be able to display that empathy honestly. Any form of insincerity, deception or lies on the part of the interviewer and any bond that may have been established will be broken and the interview will collapse into standard policing Q\&A or an interrogation.

5 Holmberga U. Madsena, K. Rapport Operationalized as a Humanitarian Interview in Investigative Interview Settings, Psychiatry, Psychology \& Law, 2, 2014 


\section{Open-ended questions}

Closed questions, like "Were you driving the car last Saturday?" are interrogative. They also limit an answer to a "yes" or "no". They do not elicit a response or compel a person to explain. Closed questions are more of a statement, essentially, than a question. Closed questions are the cornerstone of the traditional interrogation method - establish an accusation and continue to pound the subject down with closed questions that primarily serve to reinforce the accusation of guilt, as if repetition of a single line of questioning were a means of establishing fact. The primary goals of this method of interviewing is to achieve a confession.

In Dr. Karl Roberts 2012 article in the Internet Journal of Criminology, "Police Interviewing of Criminal Suspects: A Historical Perspective", he sites research conducted by Moston and Engelberg in 1993, who examined 118 taped police interviews. "They found the most common interviewing style was confrontational and confession-seeking. Here interviewers often directly accused the suspect of having committed the crime and then asked the suspect to confirm this. If the suspect remained silent, showed resistance or denied the allegation interviewers frequently moved on to persistent repetitive questioning, ignored the suspect or closed down the interview," Roberts states.

Closed questions, along with accusatory statements and authoritarian posturing from interviewers, stimulates avoidant behaviour in subjects. In his presentation of his 2009 study involving Swedish Customs Police, and based on previous research of the psychology of guilt and innocence, Prof. Pär-Anders Granhag states that: "Guilty suspects' decision control is assumed to be influenced by aversion, which will result in avoidant strategies. Chief among avoidant strategies, and the most common and frustrating for interviewers, is a "no comment" interview or simply remaining silent and looking down at the ground or at the interview table.

A guilty person's decision control can be positively affected or minimally neutralised through the use of the PEACE interview framework. It is not only the tone of the interview and the approach to holding a discussion with a subject that is transformative with the PEACE model. A well trained interviewer must understand human behaviour and emotions and how behaviour and emotions affect communication and subsequent behaviour.

So within an effective PEACE interview, open questions should be used to establish rapport and to elicit free recall from a subject. But they should be used in careful conjunction with specific closed questions, avoiding forced questions or complex, multiple choice questions that can confuse a subject and unethically trap a subject into a limited options response. 
According to the UK College of Policing, " "some types of questions are useful, helping the interviewer to extract information from the interviewee, e.g. open-ended. Others are not and may actually confuse the interviewee or prevent them from giving a full and accurate account, e.g. multiple questions."

Open-ended questions, unlike closed questions and not related to "closed specific questions" that provide controlled direction for the interviewer, require an explanation or multiple explanations from the subject. These are freestyle narrative responses which can be challenged at any time during the interview or during follow-up interviews when facts can be checked. They elicit a version of events in the subject's own words. It may be then the subject's own words which come back to haunt them later. But as the narrative came from the subject himself/herself, there was no coercion, making the interview more ethical.

Open-ended questions, like "Tell me what happened the other day", also serve to establish or re-inforce rapport. They engage the subject and display a genuine interest in his/her version of events. The key is for the interviewer to let the subject speak, not to interrupt or to corrupt the narrative with input from the interviewer.

But there are times to use specific closed questions or targeted closed questions. After a subject has responded to an open question, the interview may follow with a specific closed question. If the interviewer is in any doubt of the veracity of the previous statement made by the subject, he should follow with a question designed to challenge the previous statement. However, that follow on challenging closed question must be put to the subject with the same conversational, non-confrontational approach as in all the interview.

Example:

A suspect has been arrested on suspicion of car theft. The owner of the vehicle reported it stolen at 11:30 a.m. on the $3^{\text {rd }}$ of October. The driver, now under arrest, was pulled over by police driving the alleged stolen vehicle.

Police have the victim's statement and recordings of his call to police about the theft of his vehicle. Police have CCTV footage from a public parking lot of the suspect entering the driver's side of the vehicle and pulling out of the parking area in the vehicle.

Police take a free recall statement, written by the suspect, of his version of events. According to that statement, the suspect's friend lent him the vehicle.

Police conduct a PEACE interview. After establishing the suspect's version by use of open questions, they begin introducing evidence into the conversation. So when the suspect states that his friend gave him the keys to the car and

$6 \quad h t t p: / / w w w . a p p . c o l l e g e . p o l i c e . u k / a p p$-content/investigations/investigative-interviewing, October 23, 2013 
told him where it was parked, the interviewer produces still images from the CCTV corroborating that the suspect used the vehicle's keys to enter the car and did not, indeed, break into it. The interview follows by asking how it was, did the suspect think, that his friend later reported it stolen. The questions have gone from open and general to specific and targeted, always asking if there was an innocent explanation for why or how something happened.

This kind of "funnel" approach of starting general and open in the line of questioning and the structure of the questions themselves, when properly executed, can ease a subject into having to or being willing to explain greater and greater details.

In the scenario above, the subject tells police that his friend called him from the road and they ended up getting into a fight over the fact that the suspect was now dating the vehicle owner's previous girlfriend. Some 30 minutes after they had hang up the phone, the suspect says, the police pulled him over and arrested him.

A search of the suspect's phone reveals he was telling the truth about the call and the timing.

The combination of establishing rapport, putting the suspect in the right, non-confrontational emotional state (stimulating cooperation rather than psychological avoidance), asking open questions, presenting evidence strategically in a non-accusatory manner and following with targeted closed questions ultimately revealed the truth of the case.

\section{Overcoming bias}

One of the greatest challenges to interviewers, often blocking them from establishing rapport or from allowing a subject free recall or allowing alternative theories to emerge, is bias.

Biases are natural and are common. Biases are like blinders placed on racing horses. As they help the horse to focus on what is in front, on the finish line, and not to get overly distracted by a neighbouring horse racing on either side, biases make for quicker decision-making, they help people feel justified and certain of choices, and they play a role in helping people identify with and assimilate into a particular social group, which helps them with a human need to belong and to be accepted.

But bias handicaps the interviewer. Bias forbids rapport with anyone who falls on the wrong side of one's bias for acceptance. Bias forces judgements on people and facts that may not be justified. Bias blinds and makes deaf the 
interviewer, causing important information or actionable intelligence to be missed or ignored. Under bias, a person sees what he/she wants to see.

Bias can be based on many things, including race, gender, religion, physicality, morality, etc. Any form of bias is destructive for the interviewer.

And the most common form of bias for police interviewers around the world, due to performance pressure, is confirmation bias. The desire to see a certain subject as "good for it" or as someone likely to commit a certain type of crime, coupled with time pressure and political pressure from one's superiors, and the trigger for confirmation bias is set in motion. Soon the investigation team and interviewers are fitting facts, statements and physical evidence to support the bias. This leads to miscarriages of justice. ${ }^{7}$

\section{Active listening}

Truly hearing what a subject is saying or is trying to say and incorporating ideas, emotions or phrases a subject uses resets one's more commonly passive listening mode to active listening mode. Active listening, a fundamental component of authentic conversations, enhances rapport and aides in capturing information and nuances.

For the interviewer, it is important to concentrate on word choice, body language, syntax, colloquial expressions, coded language, and a whole host of other linguistic clues that might reveal important information or details about the subject and the event. The interviewer, having established rapport and by applying active listening properly, can and should use the subject's own words to challenge statements of "fact" presented by the subject at various times during the interview and the investigative process.

A subject will always provide signals as to areas of sensitivity, hidden emotions triggered by words or through words that trigger memories that connect to a variety of emotions. Listening carefully, and observing body language, will provide the interviewer with tools for how best to speak to the subject. Adapting one's manner of speaking and word selection can make all the difference whether a subject cooperates or not.

In a fraud investigation, for example, when I used at the start of the interview words such as "fraud" or "embezzlement" or "theft", the subject became defensive and uncooperative. When I shifted to allowing and motivating the subject to tell his version of the story, the reasons for his negative reaction and resistance to words like "fraud" became clear. He left a vital clue as to his personality and emotional need. He revealed the cognitive dissonance he wrestled

7 Roberts, K. Police Interviewing of Criminal Suspects: A Historical Perspective, Internet Journal of Criminology, 2012, 5 
with between committing a crime and wanting himself and others to believe he was a good man who did what he did for a good reason.

According to the subject, he was merely trying to get shareholders' attention to the problems of the company so that he could save the company. When all his efforts to get them to put more money into the business failed, he explained, he took the money that was in the bank account in order to force the shareholders "to pay attention". I asked him if the money he stole was "attention money". He smiled, sat up straight and proud and confident and said "yes, it was attention money". Once we referred to the fraud and theft of funds as "attention money", he confessed to everything and proudly explained exactly how he committed the crime and where the money was.

\section{Engage and explain}

One of the best ways to begin the interview is to explain to the subject the reason for the interview. And by combining the framing of expectations of the why and how of the interview with a genuine display of interest in the interviewee, the likelihood of calming the subject down, establishing rapport and creating some positive emotions to neutralise fear and aggression increases.

Regardless of a country's legal framework, a suspect should be entitled to be presented the case before him/her. The facts and circumstances surrounding the case should be explained carefully to be sure there is no misunderstanding or lack of understanding. There should be no room for a defence to later claim an unfair process.

From an interviewer's point of view, establishing the facts of the case and explaining them carefully and systematically to a suspect provides tremendous opportunity to observe the subject's response to certain pieces of evidence, to certain accusations or claims, to introductions of certain people, etc.

Subjects should be given opportunities throughout the interview to respond and to provide their version of events, particularly during the orchestrated presentation of evidence, piece by carefully selected piece.

This method of explaining and asking pertinent questions and questioning the answers by asking for further clarification, when timed right and sequenced optimally, also has the benefit of creating cognitive load for the subject. Every detail (dates, times, names of individuals, justifications, etc.) will be challenged. Accurate recall is difficult enough for a person recalling an actual event. Maintaining fabricated memories is that much harder. The mind must work many functions to create, store and recall the lie. 
The heavier the cognitive load, the more lies a person must create to protect an initial lie, the more one must remember details and timing, the more difficult it is for a person to maintain the lie.

\section{Review \& analyse (statements, body language, facts, theories, etc.)}

It is vital to step back from each interview segment and review what was said and how it was said. Explanations must be checked against previous known facts. New versions presented by the subject must be investigated, fact-checked, verified.

And the subject behaviour throughout the interview should be analysed as well. How did the person react to certain topics or names or pieces of evidence? What non-verbal communication messages were transmitted? What new information was imparted and why? What is the person's motivation to say certain things a certain way?

There are dozens of pertinent questions that can and should be asked of the investigative team after each interview segment. The analysis should lead to a refined approach in subsequent interviews. Or it may lead to focus on a single aspect of the case. Or the analysis may lead to no longer considering a certain subject valuable to the case.

\section{Statement Analysis}

Statements made by suspects, witnesses and victims should be treated with the same forensic care and attention to detail as DNA, fingerprint, ballistic or computer hard disc analysis. Forensic linguistic analysis of statements, or Statement Analysis, should be a primary investigative tool, as it aides in case establishment, theory development, investigative interviewing strategy \& tactics planning, forensic evidence gathering, veracity testing, suspect-witness-victim profiling, etc.

The process requires training in at least basic aspects of psycholinguistics, linguistics and psychology, particularly around the principles of behavioural communications. The analysis combs for indicators of deception (deception leakage) or sensitivity to certain topics, which might be flagged by shifts in verb tense, by the use of "we" instead of "I", by the frequent use of possessive 
pronouns like "my" and "mine", 8 repetition of certain words, crossing out of certain words, passive voice instead of active voice, etc.

The use of language can also yield a lot of information about a subject's personality or state of mind or emotions at the time of writing the statement, or it may reveal valuable insights into the author's feelings towards a victim or towards a perpetrator.

In one murder investigation in which my team and I provided Statement Analysis and psycholinguistic profiling, the suspect, who had stabbed another man to death more than 11 times, was arrested on first degree murder charges. The suspect claimed self-defence, which, if convicted, would bring a sentence of less than 10 years in prison compared to a life sentence for murder in the first degree. The suspect described coming into possession of the knife three different ways within the same police interview. At one point, he said he "discovered the knife," at another time he said the victim "produced the knife" and on a third occasion he said he "noticed the knife". His varying versions of the event represented a lack of conviction in his statement. Collectively, they indicated his genuine belief, despite intense pressure from police to confess to the murder, that he did not willingly or actively take a knife into his hand and stab the victim.

The suspect's statement analysis, coupled with our analysis of the statements of several witnesses, proved the witnesses had been pressured by police and had therefore lied in their statements and it proved that the suspect was in fact defending his life from a forceful and determined attack by the victim.

\section{Re-interview}

Time pressure and the ever-present push to close cases and secure convictions often leave police attempting to get all they can out of a subject in one interview. But exhausting a subject and keeping them trapped in an interview room leads to false confessions (a person will say anything to make the interview stop or to earn a chance to sleep or to have a smoke or to go to the bathroom). And exhausted investigators also make mistakes in interviews.

There is a great deal to be gained by re-interviewing a subject. Giving a person time to think about what they said, about what questions were put to him/ her and why certain questions were asked, can yield either greater, more complicated lies which will ultimately weaken a suspect's defence or can cause the subject to rethink the wisdom of lying. Either outcome is gold for an interviewer.

8 Adams, S. H. Statement Analysis: What Do Suspects' Words Really Reveal?, FBI Publications, Oct 1996

[152] NBP • Žurnal za kriminalistiku i pravo 
Follow up interviews also provide investigators time to gather new evidence, speak to new witnesses, develop altogether new lines of enquiry, develop new leads and to re-sequence or refine the timeline. All of this further strengthens the case and weakens lame excuses provided by a lying or "no comment" suspect or an uncooperative witness.

\section{Conclusion}

The more relaxed and open the interview style, the stronger the rapport established, the better the presentation of evidence, the more conversational the interview, the better the results. A well-managed, fluid interview increases the likelihood of more truth emerging in the case, increases the chance of gaining actionable intelligence and creates less need in a subject to lie or to display avoidant behaviour during the interview.

A person's recall improves during a relaxed state. This aides in witness interviews but also aides in eliciting details that can emerge from a suspect interview as well. At the same time, a well-trained interviewer can both elicit a free recall narrative from a subject and challenge the version without breaking rapport or emotionally driving the subject to retreat into avoidant behaviour, which includes silence and "no comment" replies. This is where the art of conversation, the strategic use of evidence (SUE) and deployment of psychological techniques like increasing cognitive load must merge into a fluid, non-confrontational dance between interviewer and interviewee.

Through active listening and careful note-taking (and by reviewing of audio and video recordings of the interview), an interviewer can effectively challenge a subject's version of events. And by doing so methodically and with the right pace, together with the use of open-ended questions and closed-targeted questions designed for clarification or challenging a version of events, a skilled interviewer can increase the cognitive load of the subject, making the maintenance of a lie increasingly difficult.

Most lies are structured in advance in the narrator's mind. And most liars prepare only a certain segment of a narrative and only certain details he/she thinks will cover him/her and will satisfy investigators. Recalling something that never happened is impossible. It requires imagination and quick thinking. Delivering the lie requires performance, the illusion of rationality, conviction and logic. It requires brain power and a lot of it.

The more details an interviewer can challenge, the more a lying subject must invent, and therefore the more details he/she must remember down the road at later stages in the interview. Logic becomes fuzzy. And when one is 
asked to justify his/her own fuzzy logic, to account several times in several different ways what happened during gaps in dates and times, to explain inconsistencies in his/her narrative, to clear up contradictions, the harder the subject must work mentally. The brain has a certain capacity to process all the processes it is responsible for. At one point, when enough cognitive load has been placed on a subject, the brain must decide between breathing and maintaining gravitational balance or continuing to use all is reserves to maintain the lie.

When given an opportunity to find an exit from a dilemma, when helped to get things off one's chest, when being heard and listened to or when being taken seriously or shown respect, when given a chance to lessen a punishment is presented in the right manner, many people will respond favourably eventually. This includes suspects, witnesses and victims. A properly run interview can be therapeutic in a way for subjects. It provides a comfortable environment and structured conversation to discuss and open up about uncomfortable things.

Effective interviewing should aim to seek truth or actionable intelligence. Its goal should never be to achieve a confession or to simply run through the motions as a means of closing a case as quickly as possible.

The interview is an integral part of the investigation. It can be used to develop new leads, to secure additional evidence or better evidence, and to build solid material for convictions of the guilty or exonerations of the innocent.

\section{References}

1. Dave Walsh \& Ray Bull, How Do Interviewers Attempt to Overcome Suspects' Denials, Psychiatry, Psychology \& Law, 5

2. Dr. Eric Shepherd \& Andrew Griffiths, Investigative Interviewing: The Conversation ( $2^{\text {nd }}$ Edition, 2013), Oxford University Press

3. Dr. Karl Roberts, Police Interviewing of Criminal Suspects: A Historical Perspective, Internet Journal of Criminology, 2012, 5

4. http://www.app.college.police.uk/app-content/investigations/investigative-interviewing, October 23, 2013

5. Isabel Picornell, Analysing Deception in Written Witness Statements, Linguistic Evidence in Security, Law \& Intelligence, Vol. 1 (No. 1) 2013

6. Susan H. Adams, Statement Analysis: What Do Suspects' Words Really Reveal?, FBI Publications, Oct 1996

7. Ulf Holmberga \& Kent Madsena, Rapport Operationalized as a Humanitarian Interview in Investigative Interview Settings, Psychiatry, Psychology \& Law, 2, 2014

[154] NBP • Žurnal za kriminalistiku i pravo 


\section{EFIKASNO ISTRAŽNO INTERVJUISANJE: KAKO PRETVORITI ISLEĐIVANJE U RAZGOVOR}

\section{Stiven Grosman}

Sykes \& Burrows, London, Velika Britanija

Sažetak: Ispitivanje je u osnovi borbeni monolog pod visokim pritiskom, pa stoga najčešće i negativno nabijen, kojim ispitivač pokušava da dobije priznanje od nekog lica. U tom smislu, iz svake etičke, efikasne prakse istražnog intervjuisanja trebalo bi ukloniti sledeće: borbeni pritisak, monolog i priznanje.

Efikasno, etičko istražno intervjuisanje trebalo bi da ima odlike konverzacije, da bude neborbeno i ne bi trebalo da teži izvlačenju priznanja kao primarnom cilju. Pritisak na lica (bilo da je reč o osumnjičenima, svedocima ili žrtvama) prisiljava ljude da lažu, da prestanu da govore ili da odbijaju saradnju. Pritisak i optužbe izazivaju odbrambene odgovore. Isto tako, oni izazivaju paniku i strah koji utiču na kognitivnu sposobnost osobe da se seti, pa čak i da komunicira. Koliko često ljudi u šoku zamuckuju, ili čak nisu u stanju da sastave koherentnu rečenicu ili da se sete pitanja koje im je postavljeno nekoliko sekundi pre toga?

Ako kombinujemo zastrašenost od ispitivanja od strane policije, strah od odlaska u zatvor i poniženje što će nadležni organi ili sopstvena porodica i prijatelji doneti loš sud o njima, vrlo je lako da neko završi tako što će prilikom intervjuisanja doći u stanje „bez komentara“ ili izgovoriti čiste laži. Prisiljavanje lica da prizna određenu verziju događaja kako bi se prevazišlo stanje odgovora „bez komentara“ ili čistih laži dovodi do niskih stopa osuda i pogrešnih osuda.

Alternativa koja se pokazala kao visoko efikasna kada se sprovodi u okviru dobro definisanog i kontrolisanog procesa, jeste konverzacija kojom se upravlja, a koja opušta lice i stvara sredinu i okvir komunikacije koji inspirišu razmenu.

Ključne reči: istraga, intervju, profilisanje, isleđivanje, pregovaranje. 
